\title{
A Short and Efficient Synthesis of $(R)$-Phoracantholide I
}

\author{
A. Sharma and S. Chattopadhyay* \\ Bio-Organic Division, Bhabha Atomic Research Centre, Mumbai - 400 085, India. \\ Fax: 91-22-5560750. Email: bod@magnum.barct1.ernet.in
}

Received: 16 January 1998 / Accepted: 26 January 1998 / Published: 13 February 1998

\begin{abstract}
A short and efficient chemoenzymatic synthesis of the title compound has been developed. The salient features of the synthesis were i) preparation of the required chiron via a porcine pancreatic lipase (PPL) catalyzed esterification of a $\omega$-functionalized 2 -alkanol and ii) use of easily accessible and inexpensive materials/ reagents.
\end{abstract}

Keywords: Phoracantholide I, enantioselective synthesis, lipase catalyzed resolution

\section{Introduction}

Enzymes show great promise as efficient catalysts in asymmetric synthesis and several biocatalytic protocols have been developed [1a,b] for enantioselective organic transformations. In this context, the utility of biocatalysts for the preparation of useful chirons has been appreciated in recent times. In addition, other attributes of enzyme chemistry viz. functional specificity, regio- and chemoselectivity, high catalytic rate even under moderate conditions etc. provide useful advantages for designing suitable chirons [1b]. Thus, a chemoenzymatic protocol ensures good enantiocontrol and higher efficiency of the synthesis by providing operationally simple and shorter protocol. With this aim, we have developed [2a-e] several enzymatic protocols for the preparation of useful chirons and applied [3] them to the syntheses of different bioactive compounds.

Earlier, we formulated a lipase catalyzed transesterification strategy for the resolution of alkan-2-ols which however, were not useful synthons due to the lack of adequate functionality. Hence, we tested the applicability of the above method for the resolution of $\omega$-functionalized alkan-2-ols using 1-tert-butyldimethylsilyloxy-8hydroxynonane (7) as the model compound. Subsequently, this was derivatized to $(R)$-phoracantholide $\mathrm{I}((R)-\mathbf{I}$, or 10) which is presented in this paper. Compound $R$-I constitutes [4] one of the components of the highly odoriferous defense secretion from the metasternal gland of the eucarypt longicorn, Phoracantha synonyma. Since natural $(R)$-I is known [5] to possess $(R)$-configuration, we have prepared the natural isomer only. Several syntheses of $(R)$ I in racemic [6] and chiral forms [7a-c] have already been reported. However, most of these involved multiple steps/ and or used rather inaccessible and expensive reagents. In comparison, the present one (Scheme 1) involving a chemoenzymatic route is by far the simplest and most efficient synthesis of $(R)$-I.

\section{Results and Discussion}

Thus, hexane-1,6-diol (1) was partially brominated [8] to give the known compound 2 [9] which on silylation furnished 3. $\alpha$-Alkylation of methyl acetoacetate (4) with $\mathbf{3}$

\footnotetext{
* To whom correspondence should be addressed.
} 
followed by alkaline hydrolysis gave the ketone $\mathbf{5}$. Its reduction with $\mathrm{NaBH}_{4}$ afforded the key carbinol synthon 6 which was subjected to porcine pancreatic lipase (PPL) catalyzed trans-acylation under different conditions viz. different acylating agents and solvents, and extent of conversion. The best result was obtained with trifluoroethyl butyrate (TFEB) as the acyl donor in diisopropyl ether when at $30 \%$ conversion, the $(R)$-butyrate 7 and $(S)$-6 were obtained with $93 \%$ and $78 \%$ ees respectively. The \%ee of the butyrate 7 was assayed by the GLC analysis of its ( $R$ )-MTPA ester on 3\% OV-17 column
GLC, temperature programming $140-240{ }^{\circ} \mathrm{C}, 4^{\circ} \mathrm{C} / \mathrm{min}, \mathrm{t}_{\mathrm{R}}$ $=18.6 \mathrm{~min}$ and $19.2 \mathrm{~min}$ for $(R)-6$ and $(S)-6$ respectively. The configurational assignments were inferred from the general trend [3] of PPL catalyzed acylation of 2-alkanols and their derivatives. For further confirmation, the ester 7 was converted to the known [10] compound 2-nonanol via alkaline hydrolysis, pyranylation, desilylation, mesylation, LAH reduction and depyranylation. Comparison of the sign of its optical rotation with those reported confirmed its $(R)$ - configuration.

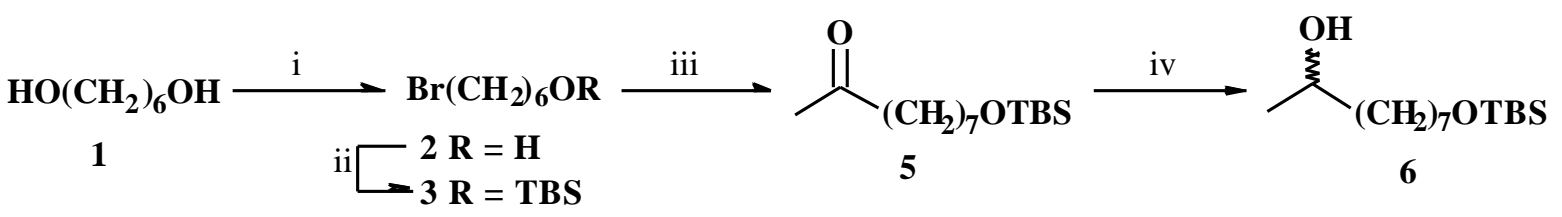

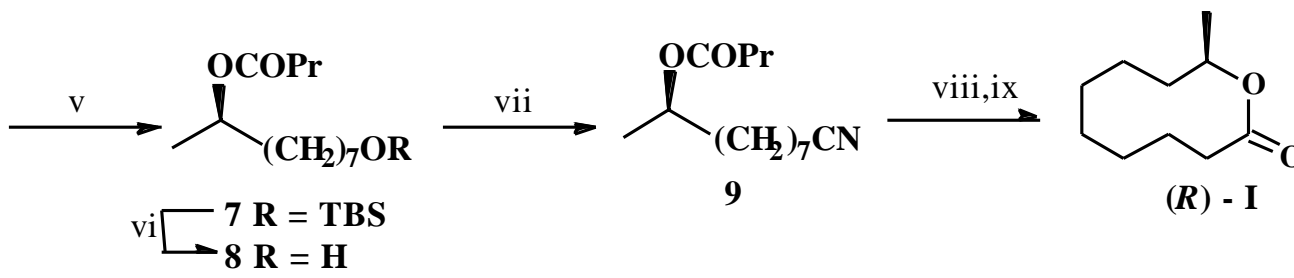

\begin{abstract}
i) $48 \% \mathrm{HBr} /$ benzene/ $\Delta$, ii) TBSCl/triethylamine/DMAP/CH ${ }_{2} \mathrm{Cl}_{2}$, iii) $\mathrm{CH}_{3} \mathrm{COCH}_{2} \mathrm{CO}_{2} \mathrm{Me}(4) / \mathrm{NaOMe} / \mathrm{MeOH}$; Aqueous $\mathrm{NaOH} / \mathrm{H}+$, iv) $\mathrm{NaBH} 4 / \mathrm{MeOH}$, v) PPL/TFEB/diisopropyl ether, vi) $\mathrm{Bu}{ }_{4} \mathrm{NF} / \mathrm{THF}$, vii) $p$-TsCl/pyridine/ $\mathrm{CH}_{2} \mathrm{Cl}_{2} ; \mathrm{KCN} / \mathrm{DMSO} / \Delta$, viii) Conc. $\mathrm{HCl} / \Delta$, ix) Alcoholic $\mathrm{KOH} ; \mathrm{H}+$.
\end{abstract}

Scheme 1.

For the synthesis, 7 was desilylated to give the alcohol 8. Its tosylation followed by reaction with $\mathrm{KCN}$ afforded the cyanohydrin derivative 9. This on acidic hydrolysis, deesterification with alkali and subsequent acidification furnished $(R)$-I. Its spectral and chiroptical data were similar to those reported [7a]. Based on the optical purity of the starting chiron and the literature data of the $[\alpha]_{D^{-}}$ value of $(R)-\mathbf{I}$, the synthetic compound should be $93 \%$ optically pure.

\section{Experimental Section}

All the boiling points are uncorrected. The IR spectra were scanned with a Perkin-Elmer spectrophotometer model 837. The ${ }^{1} \mathrm{H}-\mathrm{NMR}$ spectra were recorded in $\mathrm{CDCl}_{3}$ with a Bruker AC-200 (200 MHz) instrument. The optical rotations were measured with a Jasco DIP 360 polarimeter. The GLC analyses were carried out using Shimadzu GC7A chromatograph fitted with stainless steel column and flame ionization detector using 3\% OV-17 (2 Mt. x 0.5 $\mathrm{mm}$ ) column and a $\mathrm{N}_{2}$ flow rate $40 \mathrm{~mL} / \mathrm{min}$. Anhydrous reactions were carried out under Ar using freshly dried solvents. The organic extracts were dried over anhydrous $\mathrm{Na}_{2} \mathrm{SO}_{4}$. For enzymatic resolution PPL (Sigma, sp. act. 52.4 units/mg) was used as obtained.

\section{1-tert-Butyldimethylsilyloxy-6-bromohexane (3)}

A mixture of hexane-1,6-diol (11.8 g, $0.1 \mathrm{~mol})$ and $48 \%$ aq. $\mathrm{HBr}(16.9 \mathrm{~mL}, 0.1 \mathrm{~mol})$ in benzene $(150 \mathrm{~mL})$ was refluxed for $30 \mathrm{~h}$ with continuous azeotropic removal of water by a Dean-Stark apparatus. The mixture was washed with water, $10 \%$ aqueous $\mathrm{NaHCO}_{3}$, water, brine and dried. Removal of solvent followed by distillation gave pure 2 . yield: $10.8 \mathrm{~g}(60 \%)$; bp: $88-89^{\circ} \mathrm{C} / 2 \mathrm{~mm}$, (lit. [9] bp: $88-90^{\circ}$ $\mathrm{C} / 2 \mathrm{~mm}$ ); IR: 3350, 1480, $1460 \mathrm{~cm}^{-1}$; ${ }^{1} \mathrm{H}-\mathrm{NMR}: \delta 1.2-2.1$ $\left(\mathrm{m}\right.$, partially $\mathrm{D}_{2} \mathrm{O}$ exchangeable, $\left.9 \mathrm{H}\right), 3.54(\mathrm{t}, J=7 \mathrm{~Hz}$, $2 \mathrm{H}), 3.72(\mathrm{t}, J=7 \mathrm{~Hz}, 2 \mathrm{H})$.

A mixture of $2(1.81 \mathrm{~g}, 0.01 \mathrm{~mol}), \mathrm{TBSCl}(1.66 \mathrm{~g}$, $0.011 \mathrm{~mol})$, triethylamine $(1.53 \mathrm{~mL}, 0.011 \mathrm{~mol})$ and DMAP $(0.122 \mathrm{mg}, 1 \mathrm{mmol})$ in $\mathrm{CH}_{2} \mathrm{Cl}_{2}(50 \mathrm{~mL})$ was stirred at room temperature for $14 \mathrm{~h}$. The mixture was poured into water, the organic layer separated and the aqueous layer extracted with $\mathrm{CHCl}_{3}$. The combined organic extract was 
washed with water, and brine, dried and concentrated. The crude product was purified by column chromatography (silica gel, $0-10 \%$ EtOAc/hexane) to give 3. Yield: $2.6 \mathrm{~g}$ (88\%); IR: $1455,1440 \mathrm{~cm}^{-1}$; ${ }^{1} \mathrm{H}-\mathrm{NMR}: \delta 0.12$ (s, 6H), 0.88 (s, 9H), 1.3-1.9 (m, 8H), 3.4-3.6 (m, 4H).

\section{1-tert-Butyldimethylsilyloxynonan-8-one (5)}

To a stirred solution of $\mathrm{NaOMe}$ [prepared from $\mathrm{Na}$ $(0.343 \mathrm{~g}, 14.9 \mathrm{mmol})$ in anhydrous $\mathrm{MeOH}(20 \mathrm{~mL})]$ was added $4(1.73 \mathrm{~g}, 14.9 \mathrm{mmol})$. After the initial reaction subsided, the mixture was refluxed for $0.5 \mathrm{~h}$, cooled to room temperature and the bromide $3(4.0 \mathrm{~g}, 13.6 \mathrm{mmol})$ in $\mathrm{MeOH}(20 \mathrm{~mL})$ added to it followed by NaI $(0.1 \mathrm{~g})$. The mixture was refluxed for $18 \mathrm{~h}$, cooled to room temperature and concentrated in vacuo. Aqueous $2 \mathrm{~N} \mathrm{NaOH}(20 \mathrm{~mL})$ was added to the residue and stirring continued for $12 \mathrm{~h}$ at room temperature. It was acidified to $\mathrm{pH} 6$ with aqueous $2 \mathrm{~N} \mathrm{HCl}$, extracted with ether, the ether layer washed with water and brine and finally dried. Removal of solvent followed by column chromatography (silica gel, $0-10 \%$ EtOAc-hexane) of the residue gave pure 5. Yield: $1.77 \mathrm{~g}$ (48\%); IR: $1720,1460,1450 \mathrm{~cm}^{-1}$; ${ }^{1} \mathrm{H}-\mathrm{NMR}: \delta 0.12(\mathrm{~s}$, $6 \mathrm{H}), 0.88(\mathrm{~s}, 9 \mathrm{H}), 1.1-1.6(\mathrm{~m}, 10 \mathrm{H}), 2.16(\mathrm{~s}, 3 \mathrm{H}), 2.34(\mathrm{t}, J$ $=7 \mathrm{~Hz}, 2 \mathrm{H}), 3.59(\mathrm{t}, J=6 \mathrm{~Hz}, 2 \mathrm{H})$. Anal. Calcd. for $\mathrm{C}_{15} \mathrm{H}_{32} \mathrm{O}_{2} \mathrm{Si}: \% \mathrm{C} 66.11, \% \mathrm{H} 11.84$; Found: $\% \mathrm{C} 66.29, \% \mathrm{H}$ 12.06 .

\section{1-tert-Butyldimethylsilyloxynonan-8-ol (6)}

To a cooled $\left(0^{\circ} \mathrm{C}\right)$ and stirred solution of $5(2.1 \mathrm{~g}, 7.72$ mmol) in $\mathrm{MeOH}(30 \mathrm{~mL})$ was added $\mathrm{NaBH}_{4}(0.15 \mathrm{~g}, 3.95$ $\mathrm{mmol}$ ) in portions. After $1 \mathrm{~h}$, the reaction was quenched with solid $\mathrm{NH}_{4} \mathrm{Cl}$, the mixture concentrated and the residue taken up in ether. The ether layer was washed with water and brine and dried. Removal of solvent under reduced pressure followed by column chromatography of the residue over silica gel (0-15\% EtOAc/hexane) gave pure 6. Yield: $1.65 \mathrm{~g}(78 \%)$; IR: 3360, 1465, $1100 \mathrm{~cm}^{-1}$; ${ }^{1} \mathrm{H}-\mathrm{NMR}$ : $\delta 0.12(\mathrm{~s}, 6 \mathrm{H}), 0.9(\mathrm{~s}, 9 \mathrm{H}), 1.18(\mathrm{~d}, J=6 \mathrm{~Hz}, 3 \mathrm{H}), 1.3-1.7$ $(\mathrm{m}, 12 \mathrm{H}), 2.36\left(\mathrm{~s}, \mathrm{D}_{2} \mathrm{O}\right.$ exchangeable, $\left.1 \mathrm{H}\right), 3.63(\mathrm{t}, J=6$ $\mathrm{Hz}, 2 \mathrm{H})$, 3.7-3.9 $(\mathrm{m}, 1 \mathrm{H})$. Anal. Calcd. for $\mathrm{C}_{15} \mathrm{H}_{34} \mathrm{O}_{2} \mathrm{Si}$ : \%C 65.63, \%H 12.48; Found: \%C 65.48, \%H 12.31.

\section{(8R)-1-tert-Butyldimethylsilyloxy-8-butyroxynonane (7)}

A mixture of $( \pm)-6(2.0 \mathrm{~g}, 7.30 \mathrm{mmol})$, TFEB $(1.86 \mathrm{~g}$, $10.9 \mathrm{mmol})$ and PPL $(0.5 \mathrm{~g})$ in diisopropyl ether $(40 \mathrm{ml})$ was magnetically stirred. After $18 \mathrm{~h}$, at $30 \%$ conversion ( $c f$. GLC), the reaction mixture was filtered and the residue chromatographed (silica gel, 0-20\% EtOAc/hexane) to obtain pure $(R)$-7. Yield: $0.652 \mathrm{~g}(26 \%) ;[\alpha]_{\mathrm{D}}{ }^{24}+14.18(\mathrm{c}$ 1.4, $\mathrm{CHCl}_{3}$ ); IR: $1740,1470,1230 \mathrm{~cm}^{-1}$; ${ }^{1} \mathrm{H}-\mathrm{NMR}: \delta 0.12$ (s, 6H), $0.9(\mathrm{~s}, 12 \mathrm{H}), 1.2(\mathrm{~d}, J=6 \mathrm{~Hz}, 3 \mathrm{H}), 1.3-1.6(\mathrm{~m}$, 14H), 2.3 (t, $J=6 \mathrm{~Hz}, 2 \mathrm{H}), 3.68$ (t, $J=6 \mathrm{~Hz}, 2 \mathrm{H}), 4.0-4.3$ (m, 1H). Anal. Calcd. for $\mathrm{C}_{19} \mathrm{H}_{40} \mathrm{O}_{3} \mathrm{Si}: \% \mathrm{C} 66.22, \% \mathrm{H}$ 11.70; Found: \%C 66.08, \%H 11.61. (S)-6: yield: $1.26 \mathrm{~g}$ $(63 \%) ;[\alpha]_{D}{ }^{24}-9.36\left(\mathrm{c} 0.7, \mathrm{CHCl}_{3}\right)$.

\section{(8R)-8-Butyroxynonan-1-ol (8)}

To a cooled $\left(-78^{\circ} \mathrm{C}\right)$ and stirred solution of $7(0.6 \mathrm{~g}$, $1.74 \mathrm{mmol})$ in THF $(10 \mathrm{~mL})$ was added $\mathrm{Bu}_{4} \mathrm{NF}(1.74 \mathrm{~mL}$, $1.74 \mathrm{mmol}$ ). The mixture was stirred at the same temperature for $3 \mathrm{~h}$ and then kept at $0^{\circ} \mathrm{C}$ for $12 \mathrm{~h}$. It was diluted with water, extracted with ether and the ether extract washed with water and brine. Solvent removal and column chromatography of the residue (silica gel, $0-15 \%$ EtOAc/hexane) gave 8. Yield: $0.336 \mathrm{~g}(84 \%) ;[\alpha]_{D_{-1}}{ }^{24}$ +8.34 (c 0.86, $\mathrm{CHCl}_{3}$ ); IR: 3380, 1740, 1460, $1230 \mathrm{~cm}^{-1}$; ${ }^{1} \mathrm{H}-\mathrm{NMR}: \delta 0.9$ (dist. t, $\left.3 \mathrm{H}\right), 1.16(\mathrm{~d}, J=6 \mathrm{~Hz}, 3 \mathrm{H}), 1.2-1.6$ $(\mathrm{m}, 14 \mathrm{H}), 2.1\left(\mathrm{~s}, \mathrm{D}_{2} \mathrm{O}\right.$ exchangeable, $\left.1 \mathrm{H}\right), 2.4(\mathrm{t}, J=6 \mathrm{~Hz}$, $2 \mathrm{H}), 3.63(\mathrm{t}, J=6 \mathrm{~Hz}, 2 \mathrm{H}), 4.1-4.3(\mathrm{~m}, 1 \mathrm{H})$. Anal. Calcd. for $\mathrm{C}_{13} \mathrm{H}_{26} \mathrm{O}_{3}$ : \%C 67.78, \%H 11.38; Found: \%C 66.86, $\% \mathrm{H} 11.61$.

\section{(9R)-9-Butyroxynonanonitrile (9)}

To a cooled $\left(0^{\circ} \mathrm{C}\right)$ and stirred solution of $8(0.336 \mathrm{~g}$, $1.46 \mathrm{mmol})$ and pyridine $(0.230 \mathrm{~mL}, 2.89 \mathrm{mmol})$ in $\mathrm{CH}_{2} \mathrm{Cl}_{2}(10 \mathrm{~mL})$ was added $p$ - $\mathrm{TsCl}(0.550 \mathrm{~g}, 2.89 \mathrm{mmol})$. After stirring for $2 \mathrm{~h}$ at the same temperature, the mixture was kept in the freezer for $12 \mathrm{~h}$. It was poured into icewater, the organic layer separated and the aqueous part extracted with $\mathrm{CHCl}_{3}$. The combined organic extract was washed with water, and brine and dried. Removal of solvent in vacuo followed by column chromatography (silica gel, $0-5 \% \mathrm{EtOAc} /$ hexane) of the residue furnished the corresponding tosylate. yield: $0.500 \mathrm{~g}(89 \%)$.

A mixture of the above compound $(0.5 \mathrm{~g}, 1.3$ $\mathrm{mmol})$ and $\mathrm{KCN}(0.254 \mathrm{~g}, 3.9 \mathrm{mmol})$ in DMSO $(20 \mathrm{~mL})$ was gently heated at $80^{\circ} \mathrm{C}$ for $18 \mathrm{~h}$. After cooling to room temperature, the mixture was poured into a large excess of cold water and extracted with ether. The ether layer was thoroughly washed with water, and brine. After drying, the extract was concentrated and the crude product was purified by column chromatography (silica gel, 0-5\% EtOAc/hexane) to furnish pure 9. Yield: $0.212 \mathrm{~g}(68 \%)$; IR: 2200, 1730, $1240 \mathrm{~cm}^{-1}$; ${ }^{1} \mathrm{H}-\mathrm{NMR}: \delta 0.88$ (dist. t, $3 \mathrm{H}$ ), $1.16(\mathrm{~d}, J=6 \mathrm{~Hz}, 3 \mathrm{H}), 1.2-1.6(\mathrm{~m}, 14 \mathrm{H}), 2.1-2.3(\mathrm{~m}, 4 \mathrm{H})$, 4.0-4.2 (m, $1 \mathrm{H})$. Anal. Calcd. for $\mathrm{C}_{14} \mathrm{H}_{25} \mathrm{O}_{2} \mathrm{~N}$ : \% C 70.25, $\% \mathrm{H} 10.53, \% \mathrm{~N} \mathrm{5.85}$; Found: $\% \mathrm{C} 70.48, \% \mathrm{H} \mathrm{10.61, \% \textrm {N }}$ 6.10 .

\section{(9R)-Phoracantholide I ((R)-I or 10)}

A mixture of compound $9(0.210 \mathrm{~g}, 0.88 \mathrm{mmol})$ and conc. $\mathrm{HCl}(2.0 \mathrm{~mL})$ was stirred for $16 \mathrm{~h}$ at room temperature and subsequently at $80^{\circ} \mathrm{C}$ for $6 \mathrm{~h}$. The mixture was extracted with $\mathrm{CHCl}_{3}$, the organic extract washed with 
water, brine and dried. After concentration, the resultant crude product was directly taken up in alcoholic $\mathrm{KOH}(5$ $\mathrm{mL}$ ) and stirred for $16 \mathrm{~h}$. The mixture was concentrated in vacuo, the residue dissolved in water, acidified with conc. $\mathrm{HCl}$ to $\mathrm{pH} 2$ and extracted with ether. The ether layer was washed with water, brine and dried. Solvent removal followed by preparative TLC (silica gel, 10\% EtOAc/hexane) furnished pure $(R)-\mathbf{I}(\mathbf{1 0})$. Yield: $0.091 \mathrm{~g}$ $(61 \%) ;[\alpha]_{\mathrm{D}}{ }^{24}-32.4\left(\mathrm{c} 0.7, \mathrm{CHCl}_{3}\right)\left(\right.$ lit. $[7 \mathrm{a}][\alpha]_{\mathrm{D}}{ }^{22}-35.1$ (c $\left.1.15, \mathrm{CHCl}_{3}\right)$ ); IR: $1720,1260,1240 \mathrm{~cm}^{-1}$; PMR: $\delta 1.18$ $(\mathrm{d}, J=6 \mathrm{~Hz}, 3 \mathrm{H}), 1.2-1.6(\mathrm{~m}, 12 \mathrm{H}), 2.1-2.4(\mathrm{~m}, 2 \mathrm{H}), 4.4-$ $4.8(\mathrm{~m}, 1 \mathrm{H})$. Anal. Calcd. for $\mathrm{C}_{10} \mathrm{H}_{18} \mathrm{O}_{2}: \% \mathrm{C} 70.55, \% \mathrm{H}$ 10.66; Found: \%C 70.38, \% 10.81.

\section{References}

1. (a) Davies, H. G.; Green, R. H.; Kelly, D. R.; Roberts, S. M., Biotransformations in Preparative Organic Chemistry. The Use of Isolated Enzymes and Whole Cells Systems in Synthesis, Academic, London (1989). (b) Drauz, K.; Waldmann, H., In Enzyme Catalysis In Organic Synthesis, $\mathrm{VCH}$ Verlagsgesellschaft $\mathrm{mbH}$, Weinheim and $\mathrm{VCH}$ Publishers Inc., New York NY, USA, 1995.

2. (a) Sharma, A.; Sankaranaryanan, S.; Kulkarni, B. A.; Chattopadhyay, S. J. Org. Chem. 1991, 56, 6823. (b) Pawar, A. S; Sankaranarayanan, S.; Chattopadhyay, S. Tetrahedron Asymm. 1995, 6,
2219. (c) Sharma, A.; Sankaranarayanan, S.; Chattopadhyay, S. J. Org. Chem. 1996, 61, 1814. (d) Sankaranarayanan, S.; Sharma, A.; Chattopadhyay, S. Tetrahedron Asymm. 1996, 7, 2639. (e) Sharma, A.; Sankaranarayanan, S.; Chattopadhyay, S. Enantiomer (in press).

3. Sharma, A.; Pawar, A. S.; Chattopadhyay, S. Synth. Commun. 1996, 26, 19.

4. Moore, B. P.; Brown, W. V. Aust. J. Chem. 1976, 29, 1365.

5. Kitahara, T.; Koseki, K.; Mori, K. Agric. Biol. Chem. 1983, 47, 389.

6. Saikia, A. K.; Hazarika, M. J.; Barua, N. C.; Bezbarua, M. S.; Sharma, R. P.; Ghosh, A. C. Synthesis 1996, 981, and ref. cited therin.

7. (a) Kitahara, T.; Koseki, K.; Mori, K. Agric. Biol. Chem. 1983, 47, 389. (b) Naoshima, Y.; Hasegama, H.; Nishiyama, J.; Nakamura, A. Bull Chem. Soc. Jpn. 1989, 62, 608. (c) Nagumo, S.; Suemune, H.; Sakai, K. Tetrahedron 1992, 48, 8667.

8. Kang, S. -K.; Kim, W. -S.; Moon, B. -H. Synthesis 1985, 1161.

9. Ishihara, T.; Yamamoto, A. Agric Biol. Chem . 1984, 48, 211.

10. Keinan, E.; Hafeli, E. K.; Seth, K. K.; Lamed, R. J. Am. Chem. Soc. 1986, 108, 162.

Sample Availability: Available from the authors. 